Vol. 7 (1), pp. 001-007, January, 2017

ISSN: 2276-7762; ICV: 5.99

Copyright @2017, the copyright of this article is retained by the author(s)

DOI Link: http://doi.org/10.15580/GJBS.2017.1.122916224

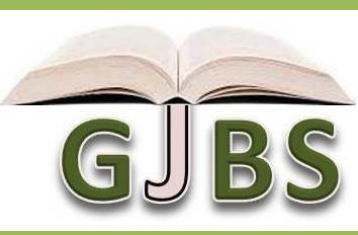

http://gjournals.org/GJBS

\title{
Antibacterial Activity and Phytochemical Screening of Carica papaya on some Enteric Bacterial Isolates of Public Health Importance
}

\author{
Yahaya A. ${ }^{1 *}$, Ali M. ${ }^{2}$ and Idris $A .^{3}$
}

${ }^{1}$ Biology Department, Faculty of Science, Kano University of Science and Technology, Wudil. P. M. B. 3244, Kano State, Nigeria

${ }^{2}$ Biological Science Unit, Ahmadu Bello University, School of Basic and Remedial studies Funtua, Katsina State, Nigeria.

${ }^{3}$ Department of Biology, Federal University, Dutse, Jigawa State, Nigeria

2Email: alimuhd4real @gmail .com, Telephone: +2347032967252

3Email: aishaidris24 @gmail .com, Telephone: +2348068071205

\section{ARTICLE INFO}

Article No.: 122916224

Type: Research

DOI: 10.15580/GJBS.2017.1.122916224

Submitted: 29/12/2016

Accepted: 03/01/2017

Published: 30/01/2017

${ }^{*}$ Corresponding Author

Yahaya A.

E-mail: yahayabdul @yahoo.com

Phone: +2348065404228

Keywords:

Antimicrobial activities, Carica papaya,

Inhibition, Phytochemical,

Entericbacteria

\section{ABSTRACT}

The study was carried out to determine the antimicrobial activities of Carica papaya and its major antimicrobial constituents (phytochemicals). The aqueous and ethanol extracts from the leaves and stem back of these plants were tested using well Diffusion method for their antimicrobial activity against some members of Enterobacteriales family isolated from diarrheic stool sample (Escherichia coli, Shigella spp, Salmonella typhi and Pseudomonas aeruginosa). Statistical analysis of the result shows that both the extracts demonstrated higher activities against bacteria tested, with the average zone of inhibition of $15.44 \mathrm{~mm}, 14.78 \mathrm{~mm}$, $12.92 \mathrm{~mm}$ and $11.31 \mathrm{~mm}$ for Shigella, Escherichia coli, Salmonella typhi and Pseudomonas aeruginosa respectively. The Minimum Inhibitory Concentration (MIC) and Minimum Bactericidal Concentration (MBC) of the extracts ranges between $12.5-100 \mathrm{mg} / \mathrm{ml}$. Preliminary phytochemical analyses showed that the extracts contain alkaloids, tannins, terpenoids, anthraquinones, reducing sugar, amino acid, flavonoids, saponins, glycosides and phenols. Demonstration of antibacterial activity against the test isolates is an indication that there is possibility of sourcing alternative antibiotic substances in these plants for the production of newer antibacterial agents. 


\section{INTRODUCTION}

Currently, there has been a lot of attention focused on producing medicines and products that are natural. Several leaves and leaf extracts have been found to have antimicrobial activity against microorganisms (Kim et al., 2004). This suggests that plants which manifest relatively high levels of antimicrobial action may be a source of compounds that can be used to inhibit the growth of food borne pathogens (Biswas et al., 2014). There is no plant that does not have medicinal value (Anibujuwon and Udeze, 2009). The active components are normally extracted from all plant structures, but the Concentration of these compounds varies from structure to structure. However, plant parts known to contain the highest concentration of these phytochemical constituents for therapeutic purpose can either be leaves, stem barks, root, bulks, corms, rhizomes, wood, flowers, fruits or the seeds (Kafaru, 1994).

The presence of phytochemical constituents in medicinal plants made them useful for healing as well as for curing of human diseases (Nostro et al., 2000). Phytochemicals are naturally occurring compounds in the medicinal plants, (Wadood et al., 2013). Large populations of the world, especially in developing countries depend on the traditional system of medicine to treat variety of diseases (McGaw et al., 2000). Several hundred genera of plants were used traditionally for medicinal purposes. The World Health Organization reported that $80 \%$ of the world population relies chiefly on traditional medicine and a major part of the traditional therapies which involve the use of plant extracts and their constituents (Ahmad et al., 1998).

Carica papaya $L$. belongs to the family of Caricaceae, and several species of Caricaceae have been used as a remedy against a variety of diseases (Mello et al., 2008). Carica papaya $L$. is commonly called pawpaw (English), Gwanda (Hausa), Ibebe (Yoruba) or Okoegbe (Igbo) (Doughari et al., 2007). It is a monosexual plant of Central American origin (Doughari et al., 2007). Besides the fruit being edible, it has been reported that the roots and the leaves have been used as antihelminthes and for the treatment of infections of bacterial origin (Fajimi et al., 2001). Papaya leave extracts have phenolic compound and caffeic acid (Ayoola and Adeyeye, 2010).Carica papaya plant produce natural compound in leaf and bark as well as twig tissues that poses both highly anti-tumor and pesticide properties (Nirosha and Mangalanayaki, 2013).

In the present research, the extracts (Both aqueous and ethanolic) from leaves and stem of Carica papaya were screened for Antibacterial activity and phytochemical analysis. The Minimum Inhibitory Concentration (MIC) and Minimum Bactericidal Concentration (MBC) of the extracts were also determined.

\section{MATERIALS AND METHODS}

\section{Plant materials}

The plant materials used in this research consisted of the leaves and stems of Carica papaya which were collected from botanical garden of Government Secondary school Gundutse, Kura Local Government Area of Kano State at about 08:30 a.m. Identification and Authentification of the plant materials has been done at Herbarium unit in the department of Biological Science Ahmadu Bello University, Zaria with the following voucher numbers 307 . Voucher specimen was then deposited there for future reference. The samples were washed with water to remove dust and rinsed with distilled water. Samples were air - dried for two-weeks and crushed into powder form using sterile mortar and pestle in the laboratory as described by Mukhtar and Tukur (1999). The powdered samples were bagged in a black polythene bag and stored in air tight container for further work.

\section{Test organisms}

Clinical isolates of Escherichia coli, Shigella, Pseudomonas aerugenosa and Salmonella typhi were obtained from Department of Microbiology of Murtala Muhammad Specialist Hospital, Kano for further study. Identification and characterization of the isolates was conducted by using three procedures namely Gram staining, cultural characterization using selective or indicative media and biochemical characterization. The pure isolates of each of the test organisms were inoculated in sterile slants containing Nutrient agar and transported to the Laboratory of Microbiology, Kano University of Science and Technology, Wudil and refrigerated at $4^{\circ} \mathrm{C}$ before use.

\section{Preparation of plant extract}

The ethanol and aqueous extract of both plant samples was carried out according to Begum (2014). $25 \mathrm{~g}$ of the powdered leaves was weight out and dissolved in $250 \mathrm{ml}$ of both solvents in a sterile beaker and allowed to stand for seven days. The mixture was filtered using Whatman No.2 filter paper and the extracts were evaporated to dryness using rotary evaporator and water bath. The solid residues obtained were reconstituted in DMSO and water at stock concentration, stored in the refrigerator at $4^{0} \mathrm{C}$ until used.

\section{Antimicrobial assay of extracts}

The agar well method was used to determine the antibacterial activity of the plant extracts. $0.1 \mathrm{ml}$ of the different standardized organisms were introduced separately and thoroughly mixed with Mueller Hilton Agar in a sterile Petri dish and allowed to set and then labelled. A sterile cork borer $6 \mathrm{~mm}$ was then used to 
punch holes (i.e. 5 wells) in the inoculated agar and the agar was then removed. Four wells that were formed were filled with different concentrations of the extract which were labeled accordingly; $200 \mathrm{mg} / \mathrm{ml}, 150 \mathrm{mg} / \mathrm{ml}$, $100 \mathrm{mg} / \mathrm{ml}$ and $50 \mathrm{mg} / \mathrm{ml}$ while the 5th well contained the solution used for the research to serve as control, tetracycline (Chi pharmaceutical limited, Lagos, Nigeria), $125 \mathrm{mg} / \mathrm{ml}$ was used as control in this research. These were then left on the bench for 1 hour for adequate diffusion of the extracts and incubated at $37^{\circ} \mathrm{C}$ for 24 hours. After incubation, the diameter of the zones of inhibition around each well were measured to the nearest millimeters along straight lines i.e. $180^{\circ}$ to each other and the mean of the readings were then calculated (Anibijuwan and Udeze, 2009).

Determination of minimum inhibitory concentration (MIC) and minimum bactericidal concentration (MBC) of the extracts

Overnight Nutrient broth cultures of E. coli, Shigella, Salmonella typhi and Pseudomonas aeruginosa at $37^{\circ} \mathrm{C}$ were prepared. The culture was adjusted to obtain turbidity comparable to that of the turbidity of McFarland 0.5 standard, and then further diluted in Nutrient broth. The inoculums thus prepared expected to obtain $1.5 \times 10^{8}$
C.F.U/ml. The MIC and MBC were determined using procedure described by Kowser and Fatima (2009).

\section{Phytochemical screening}

This was done on different extracts to ascertain the presence of bioactive component present in the leaves and stem of Carica papaya. The presence of Alkaloid, Saponin, Glycoside, Tannin, Flavonoid, Steroid, Terpenoid, Anthraquinones, Protein and amino acid were determined using procedure described by Sofowora (1993).

\section{RESULTS}

\section{Antibacterial activity}

The antibacterial activity of aqueous and ethanolic leaf extract Carica papaya is indicated in Table 1. The result showed that the mean diameter of zone of inhibition of extract on the test isolate with Shigella spp being the most susceptible isolate at $200 \mathrm{mg} / \mathrm{ml}$ concentration $(23.3 \mathrm{~mm})$ while the least was Pseudomonas aeruginosa $(6 \mathrm{~mm})$.

Table 1: Mean diameter zones of inhibition of aqueous and ethanolic leaf extract of Carica papaya CONCENTRATION MICROORGANISMS/ ZONE OF INHIBITION (mm) $(\mathrm{mg} / \mathrm{ml})$ E. Coli Shigella spp. P. aeruginosa

\section{Salmonella typhi}

\begin{tabular}{lrrrrc}
\hline \multirow{3}{*}{ ALE } & 50 & 07.6 & 08.6 & 07.0 & 07.3 \\
& 100 & 13.3 & 13.3 & 08.3 & 10.3 \\
& 150 & 16.3 & 17.3 & 11.0 & 13.0 \\
\multirow{2}{*}{ CONTROL } & 200 & 17.3 & 19.0 & 12.3 & 16.3 \\
\multirow{2}{*}{ ELE } & 50 & 18.0 & 18.6 & 17.3 & 18.6 \\
& 100 & 12.3 & 10.3 & 08.3 & 09.6 \\
& 150 & 15.3 & 16.0 & 10.3 & 15.0 \\
& 200 & 18.3 & 17.3 & 13.0 & 16.3 \\
& & 22.0 & 21.3 & 13.3 & 18.3 \\
\hline
\end{tabular}

$\mathrm{ALE}=$ Aqueous Leaf Extract, $\quad \mathrm{ELE}=$ Ethanolic Leaf Extract

The antibacterial activity of aqueous and ethanolic stem extract Caria papaya is represented in table (Table 2). The result indicated that the mean diameter of zone of inhibition of extract on the test isolate with Shigella spp being the most susceptible isolate at $200 \mathrm{mg} / \mathrm{ml}$ concentration $(23.6 \mathrm{~mm})$ and Salmonella typhi the least susceptible $(11.3 \mathrm{~mm})$. 
Table 2: Mean diameter zones of inhibition of aqueous and ethanolic stem extract of Carica papaya CONCENTRATION MICROORGANISMS/ ZONE OF INHIBITION (mm)

\begin{tabular}{|c|c|c|c|c|c|}
\hline \multicolumn{2}{|c|}{$(\mathrm{mg} / \mathrm{ml})$} & \multicolumn{2}{|c|}{ E. Coli $\quad$ Shigella spp. } & P. aeruginosa & \multirow{2}{*}{$\frac{\text { Salmonella typhi }}{06.0}$} \\
\hline & 50 & 07.3 & 07.3 & 06.0 & \\
\hline \multirow[t]{3}{*}{ ASE } & 100 & 09.6 & 10.6 & 06.6 & 08.3 \\
\hline & 150 & 10.3 & 11.6 & 08.3 & 09.6 \\
\hline & 200 & 12.6 & 14.0 & 11.3 & 13.3 \\
\hline \multicolumn{2}{|c|}{ CONTROL } & 18.6 & 18.3 & 17.3 & 17.6 \\
\hline & 50 & 09.3 & 10.3 & 06.0 & 10.3 \\
\hline \multirow[t]{3}{*}{ ESE } & 100 & 12.3 & 12.0 & 07.6 & 11.6 \\
\hline & 150 & 13.6 & 15.0 & 10.3 & 12.3 \\
\hline & 200 & 16.3 & 17.3 & 12.6 & 14.6 \\
\hline
\end{tabular}

$\mathrm{ASE}=$ Aqueous Stem Extract. $\mathrm{ESE}=$ Ethanolic Stem Extract.

Minimum inhibitory concentration (MIC) and Minimum bactericidal concentration. (MBC).

Table 3 shows minimum inhibitory concentration (MIC) of the plant extracts. The result indicated that both aqueous and ethanolic leaf extracts of the plant can inhibit the growth of the test isolates at concentration of $6.25-25 \mathrm{mg} / \mathrm{ml}$. The aqueous stem extract has higher MIC of $50 \mathrm{mg} / \mathrm{ml}$ in E. coli and Shigella spp than in $S$. typhi and $P$. aeruginosa but MIC of $12.5-50 \mathrm{mg} / \mathrm{ml}$ for ethanolic extract. This shows that ethanolic extract is more effective against the test isolates.

Table 3: Minimum inhibitory concentration (MIC) and Minimum bactericidal concentration (MBC) of the Carica papaya extracts against test isolates

\begin{tabular}{|c|c|c|c|c|}
\hline \multirow{2}{*}{$\begin{array}{c}\text { CONCENTRATION } \\
(\mathrm{mg} / \mathrm{ml})\end{array}$} & \multicolumn{3}{|c|}{ MICROORGANISMS/ ZONE OF INHIBITION (mm) } & \multirow[b]{2}{*}{ Salmonella typhi } \\
\hline & E. Coli & Shigella spp & P. aeruginosa & \\
\hline ALE & $25 / 25$ & $25 / 25$ & $50 / 50$ & $50 / 50$ \\
\hline ELE & $12.5 / 25$ & $12.5 / 25$ & $25 / 50$ & $25 / 25$ \\
\hline ASE & $50 / 50$ & $0 / 50$ & 100/ND & 100/ND \\
\hline ESE & $25 / 25$ & $25 / 25$ & $50 / 50$ & $25 / 25$ \\
\hline
\end{tabular}

$\mathrm{ALE}=$ Aqueous leaf extract, ELE $=$ Ethanolic leaf extract, $\mathrm{ASE}=$ Aqueous stem extract,

$\mathrm{ESE}=$ Ethanolic stem extract, ND $=$ Not detected.

\section{Phytochemical screening}

The Table below (Table 4) showed that the phytochemicals were present in leaf and stem of Carica papaya. Leaf extract contain all the tested phytochemicals except Tannin, while stem extract contain only three phytochemicals: Alkaloids, Saponins and Flavonoids. This shows that Carica papaya leaf contain more phytochemicals than the stem.

Table 4: Phytochemical constituents present in leaves and stem of Carica papaya

\begin{tabular}{clcc}
\hline S/N & PHYTOCHEMICAL & LEAF EXTRACT & STEM EXTRACT \\
\hline 1. & Alkaloids & + & + \\
2. & Saponins & + & + \\
3. & Phenols & + & - \\
4. & Flavonoids & + & - \\
5. & Protein and Amino acid & + & - \\
6. & Tannins & - & - \\
7. & Reducing Sugar & + & - \\
8. & Anthraquinones & + & - \\
9. & Steroids & + & - \\
10. & Terpenoids & + & \\
\hline
\end{tabular}

$+=$ Presence of phytochemical, $-=$ Absence of phytochemical. 


\section{DISCUSSION}

The present study showed that the different parts of Carica papaya (leaves and stem) possess antimicrobial potential against Shigella, E. coli, $P$ aeruginosa and Salmonella typhi. In line with the present finding, several other studies have reported Carica papaya leaves to have antimicrobial potentials (Anibijuwon and Udeze, 2009; Baskaran et al., 2012; Marshall et al., 2015). The reports of Ifesan et al. (2013) have also shown that Carica papaya have significant antibacterial activity in various extracts from different tree parts. In the present study, all the extracts prepared from Carica papaya leaf and stem (water and ethanol) exhibited highest antibacterial activity against test isolates. However, the leaf extract exhibited highest antibacterial activity than the stem extract, this is attributed to more phytochemical constituents in leaf compared to stem.

From the results of MIC determination, the minimum inhibitory concentration showed that a very low concentration of $12.5-25 \mathrm{mg} / \mathrm{ml}$ of the ethanolic stem back extract inhibit the growth of all tested isolates. The aqueous stem extract of Carica papaya demonstrated that the MIC value of the extract is very high i.e. $50 \mathrm{mg} / \mathrm{ml}$ for $E$. coli and Shigella while S. typhi and $P$. aeruginosa having a value of $100 \mathrm{mg} / \mathrm{ml}$. The result of this study showed that organic extracts has lower MIC value for the tested isolates compared to aqueous extracts. These findings are in conformity with that of Ohue and Momoh (2013) in which the antibacterial activity on different solvent extracts of Carica papaya leaf on some bacteria showed that the ethanolic extract has lower value $(28 \mathrm{mg} / \mathrm{ml})$ than aqueous extract $(30 \mathrm{mg} / \mathrm{ml})$. This however, is in contrast to the results of Tewari et al. (2014) and Marshall et al. (2015) who demonstrated that the ethanol extracts had a higher activity than the aqueous extracts in both leaf and stem samples. The better efficacy of the ethanol extract as against the aqueous extract may be because different solvents have different polarities, hence different degrees of solubility for the various phyto-constituents (Anas et al., 2008). Based on the limited effect of activity of the other extracts compared with the ethanol extracts, it suggests that the active component is more soluble in ethanol than in the other solvents. These results obtained support the fact that further work needs to be done to determine and identify, purify and quantify the antibacterial compound within these plants and also to determine their full spectrum of efficacy.

In the present study, the result of the phytochemical screening of Carica papaya showed that the leaf and stem back of the plants contained some phytochemical compounds which possess good antimicrobial properties on the clinical isolates used. The phytochemical analysis of the plant leaf showed that it contains Saponins, Alkaloids, Flavonoids, Phenol, Protein and Amino acid, Steroid, Anthraquinones and Terpenoid. Based on this study, the phytochemical compounds in the leaf are more than that of the stem back that contain Alkaloid, Saponin and Flavonoids. This finding is in conformity with the work of Sikanda et al. (2013) and Marshall et al. (2015) who also reported the effect of these phytochemicals as a good antimicrobial agent on different test organisms. Reports on the effects of these medicinal plants on animal and human health are diverse. Although these effects are largely attributed to the active components of these plant materials (Zaid et al., 2002; Okenwa et al., 2012), yet information on the chemical composition of many of these plant materials are still scarce (Akpanabiatu et al., 2006).

Although the mechanism of action of this extract is not understood, it has been proposed that its action against the bacteria and fungi may be due to the inhibition of cell wall formation in the cell resulting in a leakage of cytoplasmic constituents by the bioactive components of the extract (Bais et al., 2002; Hassan et al., 2007). In addition, bioactive substances have been reported to confer resistance to plants against bacteria, fungi and pests and therefore explain the demonstration of antibacterial activity by the plant extracts used in this study (Srinivasan et al., 2001). In these regard, Aravind et al. (2013) reported that the many benefits of papaya, are due to the high content of Vitamins A, B and C, proteolytic enzymes like papain and chymopapain, that have antiviral, antifungal and antibacterial properties. While phytochemical compounds such as tannin coagulate the wall proteins, saponins facilitated the entry of toxic material or leakage of vital constituents from the cell (Onwuliri and Wonang, 2005).

Flavonoids inhibit the activity of enzymes by forming complexes with bacterial cell walls, extracellular and soluble proteins, more lipophilic flavonoids disrupt cell wall integrity (Kurtz et al., 1994) or microbial membranes (Tsuchiya et al., 1996) at low concentrations. The existence of Saponin supports the fact that pawpaw has cytotoxic effect such as permealization of the intestine as Saponins are cytotoxic (Okwu and Okwu, 2004). Alkaloids are the most efficient therapeutically influential plant substance. Pure natural and synthetic derivatives of alkaloids are used as a basic medical agent because of their analgesic, antispasmodic and antibacterial properties (Stray, 1998). The presence of Alkaloid in the pawpaw shows that this plant can be an effective anti-malaria agent since alkaloid consists of quinine, which is anti-malaria (Robinson, 1995).

Marchese and Shito (2001) and Poole (2001) reported the sensitivity of the microbial strains to both the plant extracts and to synthetic antibiotics, and observed that that the plant extracts compete favorably with the drugs and can be used as an alternative to the antibiotics as the zones of inhibition shown were very comparable and the extracts have lesser side effects which are often associated with the use of antibiotics. Also, the issue of resistance to these extracts cannot arise as is found with antibiotics (Kareem et al., 2010). 


\section{CONCLUSION AND RECOMMENDATIONS}

The medicinal uses of these plants Carica papaya are supported by the presence of phytochemical constituents present in them and the antimicrobial activities they exhibit and the phytochemical analysis of the plants is very important commercially and has great benefit in pharmaceutical companies for the production of safe and effective new drugs for treating different kinds of diseases. Demonstration of antibacterial activity against the test isolates is an indication that there is a possibility of sourcing alternative antibiotic substances in these plants for the development of newer antibacterial agents. Based on these findings, the application of the decoction of leaf and stem of the plants in ethno medicine is justified. Hence, this underscores the need to exploit the potentials of these plants especially in areas of traditional medicine and pharmaceutical industries. Therefore, it is recommended that Government, Non-governmental organizations (NGOs) and philanthropists should encourage researchers in this field so that the spread of antimicrobial resistant pathogens can be restrained.

\section{ACKNOWLEDGEMENT}

The authors wish to acknowledge the staff of Microbiology Department, Murtala Muhammad Specialist Hospital, Kano for their co-operation and sample provision. We appreciate the technical assistance of LaboratoryTechnologists of the Department of Microbiology, Kano University of Science and Technology, Wudil and that of Ahmadu Bello University, Zaria for their support and use of the department's laboratory facilities. Sincere thanks to Kano State Government through the Ministry of Health for granting us ethical clearance for the conduct of the research.

\section{COMPETING INTERESTS}

The authors declare they have no competing interests.

\section{REFERENCES}

Ahmad I, Mehmood Z and Mohammad F (1998). Screening on some Indian medicinal plants for their antimicrobial properties. Journal of Ethnopharmacology. 62: 183-193.

Akpanabiatu MI, Umoh IB, Eyong EU, Edet EE and Uboh FE (2006). Toxico-pathological changes and phytochemically-induced alleviation in Diabetic Rats Treated with Gongronema latifolium Leaf Extracts.Biopharmaceuticals. 14(13): $273-278$.

Anas K, Jayasree PR, Vijayakumar, $T$ and Manish Kumar, PR (2008). In-vitro antibacterial activity of Psidium guajava L. Leaf extract on clinical isolates of multidrug resistant Staphylococcus aureus. Indian Journal of Experimental Bioliology. 46:41-46.

Anibijuwon II and Udeze OA (2009). Antimicrobial Activity of Carica papaya (Paw-paw Leaf) on Some Pathogenic Organisms of Clinical Origin from South Western, Nigeria. Ethno Botanical Leaflets. 13: 850864.

Aravind G, Debjit B, Duraivel S and Harish G (2013). Traditional and Medicinal Uses of Carica papaya. Journal of Medicinal Plants Studies. 1(1): 7-15.

Ayoola PB and Adeyeye A (2010). Phytochemical and nutrient evaluation of Carica papaya (pawpaw) leaves. International Journal of Research and Reviews in Applied Studies. 5 (3): 325- 328.

Baskaran C, Ratha-bai V, Velu S and Kumaran K (2012). The efficacy of Carica papaya leaf extract on some bacterial and a fungal strain by well diffusion method. Asian Pacific Journal Tropical Diseases. S658-S662.

Begum M (2014). The phytochemical and pharmacological investigation of Carica papaya leaf. BSc. Dissertation (Unpublished), Department of Pharmacy, East West, University, Dhakar.

Bais HP, Walker TS, Schweizer HP, Vivanco, JM (2002). Plant Phy.Biochem.40: 983-995.

Biswas B, Kimberly FM, Dwaye D and Anand Y (2013). Antimicrobial activity of leaf extracts of Guava (Psidium guajava) on two Gram positive and two Gram negative bacteria. International Journal of Microbiology. 2: 7.

Doughari JH, El Mahmud AM and Manzara S (2007). Studies on the antibacterial activities of root extract of Carica papaya L. African Journal of Microbiology Research. Pp. 037-041.

Fajimi AK, Taiwo AA, Ayodeji $\mathrm{H}$, Adebowale EA and Ogundola FI (2001). Therapeutic trials on gastrointestinal helminthes parasites of goat using paw seeds as a drench. Proceeding of the International Conference on sustainable crop, Livestock production for improved livelihood and Natural Resource Management, West Africa. International Institute of Tropical Agriculture (IITA).

Hassan SW, Umar RA, Ladan MJ, Nyemike P, Wasagu RSU, Lawal M and Ebbo AA (2007). Nutritive Value, Phytochemical and Antifungal Properties of Pergularia tomentosa L. (Asclepiadaceae). International Journal of Pharmacology. 3(4): 334340.

Ifesan BOT, Fashakin JF, Ebosele $\mathrm{F}$ and Oyerinde AS (2013). Antioxidant and Antimicrobial Properties of Selected Plant Leaves. European Journal of Medicinal Plants. 3(3): 465-473.

Kafaru E (1994). Immense help formative workshop. In: Khan R, Islam B, Akram M, Shakil S, Ahmad A, Ali MS, Sadiqui M and Khan AU (2008). Antimicrobial Activity of Five Herbal Extracts against Multi Drug Resistant (MDR) strains of Bacteria and Fungus of Clinical Origin. Molecules.13.

Kareem KT, Kareem SO, Adeyemo OJ and Egberongbe RK (2010). In-vitro antimicrobial properties of 
Bridelia ferruginea on some clinical isolates. Agriculture and Biological Journal of North America.1(3): 416-420.

Kim S and Fung YV (2004). Antibacterial effect of crude water soluble Arrow root (Peurariae radix) tea extracts on food borne pathogens in a liquid medium. Letters in Applied Microbiology. 39(4): 319 $-325$.

Kowser M. M and Fatema N (2009). Determination of MIC and MBC of selected azithromycin capsule commercially available in Bagladesh. The Orion Medical Journal. 32(1): 619-620.

Kurtz MB, Heath IB, Marrinan J, Dreikhorn S, Onishi J and Douglas C (1994). Morphological effects of lipopeptides against Aspergillus fumigatus correlate with activities against (1,3)-beta-D-glucan synthase. Antimicrob. Agents Chem. 38 (7): 1480-1489.

Marchese A and Shito GC (2001). Resistance patterns lower respiratory tract pathogens in Europe. International Journal of Antimicrobial Agents.16: 2529.

Marshall EU, Stephen CU, Emmanuel UO and Chizaram EA (2015). Antimicrobial screening and phytochemical analysis of Carica papaya Leaf extracts. Standard Research Journal of Microbiological Sciences. 2(1): 001-004.

McGaw LJ, Jager AK and Staden JV (2000). Antibacterial, anti-helminthes and anti-amoebic activity in South Africa medicinal plants. Journal of Ethanopharmacology. 72 : $247-263$.

Mello VJ, Gomes MT, Lemos FO, Delfino JL, Andrade SP, Lopes MT and Salas CE (2008). The gastric ulcer protective and healing role of cysteine proteinases from Carica candamarcensis. Phytomedicine.15: 237-244.

Mukhtar MD. And Tukur A (1999). In-vitro screening activity of Pistia stratiutes extract. NISED Journal. 1(1): $5-6$.

Nirosha N and Mangalanayaki, R. (2013). Antibacterial Activity of Leaves and Stem Extract of Carica papaya L. Inter. J. Adv. Pharmacy, Bio. Chem. 2(3): 473-476.

Nostro A, Germano, MP, D'angelo V. Mariano A and Lanattel MA (2000). Extraction method and bioautography for evaluation of medicinal plants antimicrobial activity. Letter in Applied Microbiology. 30: 379.

Okwu D and Okwu ME (2004).Chemical composition of Spondias mombin Linn. Plant parts. J. Sustain. Agric Environ. 6 (2): 140-147.

Onwuliri FC and Wonang DL (2005). Studies on the combined Antimicrobial action of Ginger (Zingiber officinale $L$.) and Garlic (Allium sativum $L$ ) on some Bacteria. Nigeria J. Bot. 18: 224-228.

Orhue PO and Momoh ARM (2013). Antibacterial activities of different solvent extracts of Carica papaya fruit parts on some gram-positive and gram negative organisms. International Journal of Herbs and Pharmacological Research. 2(4): 42-47.

Poole (2001). Multidrug efflux pump and antimicrobial resistance in Pseudomonas and related organisms. Journal of molecular, Microbials and Biotechnology. 3:255 - 264.

Robinson S (1995). Kandungan organic Tumbuhan tinggi diterjemahkan Padnawinata $\mathrm{K}$, Edisike-6 Institute Technology, Bandung, Bandung 193.

Sikandar KS, Tasveer ZB, Kanwal N, Syed, AG and Shahama UK (2013). Qualitativephytochemical screening and antifungal activity of Carica papaya leaf extract against human and plant pathogenic fungi. International Research Journal of Pharmacy. 4 (7).

Sofowora A (1993). Medicinal plants and traditional medicine in Africa. Spectrum Books Ltd., Ibadan, Nigeria, 289pp.

Stray F (1998). The National Guide to Medicinal Herbs and Plants. Tiger Books International, London. pp.12-16.

Srinivasan D, Perumalasamy LP and Nathan ST (2001). Antimicrobial activity of certain Indian medicinal plants used in folkloric medicine. Journal of Ethanopharmacology. 94: 217-222.

Tewari BB, Subramanian $G$ and Gomathinayagm $R$ (2014). Antimicrobial Properties of Carica papaya (Papaya) Different Leaf Extract against E. coli, S. Aureus and C. albicans. American Journal of Pharmacology and Pharmacotherapeutics.

Tsuchiya H, Sato M, Miyazaki T, Fujiwara S, Tanigaki S, Ohyama M, Tanaka T and linuma M (1996). Comparative study on the antibacterial activity of phytochemical flavanones against methicillin resistant Staphylococcus aureus. Journal of Ethnopharmacology. 50: 27-34.

Wadood A, Gufran M, Jamal BS, Naeem M, Khan A,Ghaffar, R. and Asnad (2013). Phytochemical Analysis of Medicinal Plants Occurring in Local Area of Mardan. Biochemistry and Analytical Biochemistry. 2:14-44.

Zaid MA, Shama KK. And Rizvi SI (2002). Effect of (-) epicatechin in modulating calicum-atpase activity in normal and diabetic human erythrocytes. Indian Journal of Clinical Biochemistry. 17(2): 27 - 31. 